\title{
KAJIAN TENTANG PENGUATAN PARTISIPASI MASYARAKAT ADAT DALAM PENYELENGGARAAN OTONOMI DAERAH DI KALIMANTAN
}

\author{
Oleh : Windra Mariani
}

\begin{abstract}
Salah satu implementasi otonomi daerah adalah untuk menumbuhkan partisipasi aktif dari masyarakat, karena dalam keberhasilan pembangunan dan pengembangan daerah tidak hanya

berada ditangan pemegang kebijakan. Akan tetapi masyarakat secara luas termasuk masyarakat adat juga turut andil dalam menyukseskan daerah. Pemerintah sebagai fasilitator dan mitra kerja agar dapat menjadi stimulan/pendorong bagi masyarakat dalam meningkatkan

partisipasi, justru tidak menjadikannya sebagai alat untuk mendapatkan kekuasaan atau kepentingan-kepentingan oleh pihak tertentu. Dalam membangun partisipasi, tidak terlepas dari pemberdayaan masyarakat dimana hal ini akan menumbuhkan motivasi, kemampuan dan keberanian untuk dapat bersikap kritis terhadap kondisi yang dihadapi. Namun dalam meningkatkan partisipasi masyarakat terdapat hambatan-hambatan klasik yang penyelesaiannya merupakan tanggung jawab semua pihak untuk.
\end{abstract}

One of the implementation of the autonomy is to improve the active Community Participation.

The success of developing region not only on the government but also on the community.

Key Words: Partisipasi, Masyarakat Adat, Otonomi Daerah Kalimantan

\section{Pengantar}

Penyelenggaraan Pemerintah Daerah, sebagaimana diatur dalam UU Nomor 22 tahun 1999 yang telah diubah oleh UU Nomor 32 tahun 2004 memberikan keleluasan dan kewenangan kepada daerah untuk menyelenggarakan urusan rumah tangganya sendiri. Dengan semangat otonomi daerah mendorong masyarakat untuk mengatur daerahnya sendiri.

Disamping itu, dalam upaya mencapai tujuan dan cita-cita negara dan terselenggaranya kepemerintahan yang baik, peran serta masyarakat merupakan prasyarat mutlak. Dimana masyarakat merupakan komponen utama dalam penyelenggaraan otonomi, baik masyarakat kota ataupun masyarakat adat di pedesaaan. Masyarakat kota mempunyai akses yang mudah dengan penyelenggara pemerintahan sehingga memungkinkan partisipasi yang lebih luas dibanding masyarakat pedesaan. 
Seiring dengan semangat otonomi daerah yang bertujuan untuk meningkatkan keadilan, demokrasi dan kesejahteraan bagi seluruh unsur bangsa, meningkatkan keterlibatan serta partisipasi masyarakat dalam proses pembuatan kebijakan dan juga membangun saling kepercayaan antara masyarakat juga antara masyarakat dengan pemerintah. Dengan adanya partisipasi masyarakat yang aktif dan positif, maka akan berpengaruh terhadap perkembangan pembangunan terutama di daerah-daerah.

Kebijakan desentralisasi pun mengandung paradigma pokok untuk mendorong tumbuhnya demokratisasi, pelayanan publik, serta partisipasi dan pemberdayaan masyarakat daerah yang semakin tinggi. Perwujudan riil dari paradigma yang berpihak pada masyarakat tadi ditunjukkan oleh berubahnya fungsi lembaga perwakilan dan mekanisme pemilihan Kepala Daerah yang semula bersifat top-down menjadi bottom-up, sehingga pemimpin daerah benar-benar merupakan hasil dari aspirasi masyarakat lokal.

Perubahan lain yang diusung oleh kebijakan otonomi daerah yang baru adalah terjadinya pergeseran domein kewenangan dari yang meletakkan bobot tebesar pada Pusat (central government heavy) kepada pola baru yang mengakui kewenangan terbesar berada pada daerah (lokal government heavy). Disamping hal tersebut diatas, terjadi pula proses perampingan struktur kelembagaan, yang berimplikasi pada tuntutan untuk mengurangi peranan pemerintah dalam kehidupan masyarakat pada berbagai bidang.

Core Idea dari implementasi otonomi daerah adalah tumbuhnya partisipasi aktif masyarakat untuk membangun dirinya sendiri, sedangkan peran pemerintah hanya sebagai fasilitator dan mitra kerja masyarakat.

\section{Kajian Literatur}

Partisipasi sendiri dapat diartikan sebagai suatu gerakan atau kekuatan kelompok atau anggota kelompok (community/group power) yang bertujuan untuk ikut berperan atau berpengaruh dalam proses pengambilan keputusan. Dengan mengutip pendapat dari Midgley, Mathur, serta Oakley and Marsden, Jahja Hanafie (1996:130) mengemukakan bahwa issu utama dalam partisipasi kelompok adalah penekanannya pada distribusi kekuatan (power distribution), persamaan (equality), keterlibatan (involvement), pembuatan kebijakan (policy making) dan pengambilan keputusan (decision making).

Sedangkan Istilah masyarakat adat mulai disosialisasikan di Indonesia di tahun 1993 setelah sekelompok orang yang menamakan dirinya Jaringan Pembelaan Hak-Hak Masyarakat Adat (JAPHAMA) yang terdiri dari tokoh-tokoh adat, akademisi, dan aktivis organisasi parpol menyepakati penggunaan istilah tersebut sebagai suatu istilah umum pengganti sebutan yang sangat beragam. Pada saat itu, secara umum masyarakat adat sering disebut sebagai masyarakat terasing, suku terpencil, masyarakat hukum adat, orang asli, peladang berpindah, peladang liar dan terkadang sebagai penghambat pembangunan.

Dalam Kongres Masyarakat Adat Nusantara I yang diselenggarakan bulan Maret 1999, disepakati bahwa masyarakat adat adalah kelompok masyarakat yang memiliki asal usul leluhur (secara turun menurun) di wilayah geografis tertentu, serta memiliki sistem nilai, ideologi, ekonomi, politik, budaya, sosial dan wilayah sendiri (Keputusan KMAN No. 10/KMAN/1999 dalam rumusan keanggotaan). Secara lebih sederhana dapat dikatakan bahwa masyarakat adat terikat oleh hukum adat, keturunan dan tempat tinggal. Keterikatan 
akan hukum adat berarti bahwa hukum adat masih hidup dan dipatuhi dan ada lembaga adat yang masih berfungsi antara lain untuk mengawasi bahwa hukum adat memang dipatuhi. Di tingkat $\mathrm{PBB}$ telah disepakati penggunaan istilah indigenous people sebagaimana tertuang dalam seluruh dokumen yang membahas salah satu rancangan deklarasi PBB, yaitu draft of the UN Declaration On The Rights Of Indigeenous Peoples.

Pemahaman oleh masyarakat adat ternyata cukup berbeda dengan yang ditetapkan pemerintah dalam Undang-Undang No. 41 Tahun 1999, yang menyatakan bahwa masyarakat adat adalah kelompok masyarakat yang terikat oleh hukum adat, keturunan dan tempat tinggal.

Tabel 1. Pengertian Masy. Adat menurut Pemerintah \& Menurut Masy. Adat

\begin{tabular}{|c|c|c|}
\hline \multicolumn{2}{|l|}{ Pemerintah } & \multirow{2}{*}{$\begin{array}{l}\text { Pemahaman Oleh } \\
\text { Masyarakat Adat }\end{array}$} \\
\hline $\begin{array}{l}\text { Ciri Masy. Adat menurut } \\
\text { UU No. } 41 \text { Thn } 1999\end{array}$ & $\begin{array}{l}\text { Pemahaman } \\
\text { Pemerintah }\end{array}$ & \\
\hline $\begin{array}{l}\text { Terikat dan patuh pada satu } \\
\text { hukum adat tertentu }\end{array}$ & $\begin{array}{l}\text { Keterikatan dalam bentuk } \\
\text { hukum tertulis yang } \\
\text { dipatuhi dalam kehidupan } \\
\text { seharian. }\end{array}$ & $\begin{array}{l}\text { Hukum Adat bisa berupa } \\
\text { aturan lisan yang diingat } \\
\text { sepanjang generasi. }\end{array}$ \\
\hline Ada Lembaga Adat & $\begin{array}{l}\text { Struktur Lembaga } \\
\text { Formal/informal yang jelas } \\
\text { dan diwujudkan dalam } \\
\text { bentuk balai adat atau yang } \\
\text { lainnya }\end{array}$ & $\begin{array}{l}\text { Struktur lembaga } \\
\text { informal tetapi dipatuhi } \\
\text { dan menjadi bagian dari } \\
\text { kehidupan menyeluruh } \\
\text { masyarakat adat }\end{array}$ \\
\hline $\begin{array}{l}\text { Ada Wilayah hukum adat } \\
\text { yang jelas batasnya }\end{array}$ & $\begin{array}{l}\text { Belum ada kejelasan } \\
\text { konsep batas dari wilayah } \\
\text { hukum adat. }\end{array}$ & $\begin{array}{l}\text { Batas dipamahi oleh } \\
\text { masyarakat adat yang } \\
\text { biasanya menggunakan } \\
\text { batas alam }\end{array}$ \\
\hline $\begin{array}{l}\text { Masih mengadakan } \\
\text { pemungutan hasil hutan di } \\
\text { wilayah hutan dan } \\
\text { sekitarnya untuk memenuhi } \\
\text { kebutuhan hidup sehari- } \\
\text { hari }\end{array}$ & $\begin{array}{l}\text { Konsep "pemungutan hasil } \\
\text { hutan" untuk masyarakat } \\
\text { adat belum jelas karena } \\
\text { yang ada adalah } \\
\text { pemungutan hasil hutan } \\
\text { untuk usaha kehutanan }\end{array}$ & $\begin{array}{lr}\text { Konsep yang dimiliki } \\
\text { masyarakat adat adalah } \\
\text { pegelolaan. } & \text { Hutan } \\
\text { menjadi "Bank" } & \text { yang } \\
\text { akan diambil bisa } \\
\text { dibutuhkan. }\end{array}$ \\
\hline
\end{tabular}

Sumber: Lokakarya Nasional Kesepahaman Hutan Adat dalam Kawasan Hutan Negara, Jakarta 5-6 Desember 2001.

\section{Urgensi Partisipasi Masyarakat}

PENTINGNYA PARTISIPASI INI ANTARA LAIN DIKEMUKAKAN OLEH BEP FRITSCHI (ET.AL., 1993:214-215), YANG BERPENDAPAT BAHWA TERDAPAT DUA ALASAN POKOK UNTUK MENGEMBANGKAN PARTISIPASI KELOMPOK. PERTAMA, ALASAN-ALASAN YANG MENGACU KEPADA KELOMPOK SENDIRI, YAKNI BAHWA KELOMPOK BERHAK UNTUK IKUT TERLIBAT DALAM KEPUTUSAN-KEPUTUSAN YANG MENYANGKUT HARI DEPAN MEREKA. KEDUA, ALASAN YANG BERKAITAN DENGAN EFEKTIVITAS DAN EFISIENSI, DALAM PENGERTIAN JIKA KELOMPOK BENAR- 
BENAR DIBERIKAN KESEMPATAN UNTUK TERLIBAT SECARA AKTIF DALAM PROSES ORGANISASIONAL, MAKA ORGANISASI AKAN BERLANGSUNG LEBIH EFEKTIF DAN EFISIEN.

SEBAGAI ILUSTRASI MENGENAI PARTISIPASI, BANK DUNIA (1992:93) PERNAH MENYATAKAN BAHWA "BANYAK MASALAH LINGKUNGAN TIDAK DAPAT DIATASI TANPA PARTISIPASI AKTIF DARI PENDUDUK SETEMPAT". TENTU SAJA, APA YANG DIKEMUKAKAN OLEH BANK DUNIA TERSEBUT TIDAK SEMATA-MATA MELIPUTI ASPEK LINGKUNGAN, TETAPI JUGA BIDANG-BIDANG LAIN DALAM PEMBANGUNAN SUATU NEGARA DAN MASYARAKAT, SERTA KEHIDUPAN DALAM SUATU ORGANISASI BESAR MAUPUN KECIL.

Uraian diatas sekaligus menyiratkan bahwa keberhasilan pembangunan daerah di era otonomi tidak berada ditangan para pemegang kebijakan (policy holders) semata, tetapi justru terletak pada terjalinnya sinergi yang saling memperkuat (mutual interrelations) diantara pilar-pilar pembangunan daerah, yakni pemerintah daerah, kalangan dunia usaha, serta masyarakat luas termasuk kelompok masyarakat adat.

Dalam konteks kebijakan otonomi daerah, urgensi partisipasi masyarakat dalam pembangunan semakin tinggi. Sebab, jiwa atau semangat otonomi adalah kewenangan kesatuan masyarakat hukum di daerah untuk mengatur surusan rumah tangganya sendiri. Tercakup dalam pengertian kesatuan masyarakat hukum disini tidak hanya pemerintah Kabupaten/Kota saja, tetapi juga meliputi kelompok masyarakat adat, para pelaku bisnis lokal, NGO/organisasi kemasyarakatan, lembaga profesi, serta unit pemerintahan yang lebih kecil seperti Kecamatan, Kelurahan/Desa, bahkan juga Rukun Warga dan Rukun Tetangga. Namun dalam prakteknya, otonomi lebih banyak diterima oleh daerah otonom yang direpresentasikan oleh pemerintah daerah (kabupaten/kota), dibanding oleh komponen masyarakat lokal lainnya. Akibatnya, Undang-Undang Otonomi Daerah lebih mencerminkan pengaturan tentang "otonomi pemerintahan daerah" dari pada "otonomi daerah" itu sendiri. Kondisi obyektif bahwa otonomi daerah belum menyentuh masyarakat di level terbawah inilah yang diperkirakan menjadi kendala pertama dalam upaya membangun dan mengembangkan partisipasi masyarakat (lembaga/kelompok masyarakat adat).

Pada tataran yang lebih mikro, terdapat indikasi bahwa lembaga/kelompok masyarakat adat seringkali kurang mendukung secara penuh kebijakan dan program pembangunan pemerintah daerah yang bersangkutan. Hal ini bisa disebabkan antara lain oleh belum dibukanya kesempatan secara luas untuk berpartisipasi, kurangnya informasi dari pemerintah daerah tentang berbagai program yang dapat dilaksanakan secara partisipatif, atau bisa juga oleh keengganan dari lembaga adat/kelompok masyarakat adat untuk berpartisipasi dalam proses pembangunan karena alasan-alasan tertentu.

Dengan demikian, upaya mengembangkan partisipasi masyarakat adat tidak dapat dilepaskan dari dua strategi kunci, yakni: 1) dari dimensi pemerintahan (top-down), memperbaiki aspek kualitas proses dan mekanisme kebijakan publik maupun materi kebijakan yang terkait; dan 2) dari dimensi kemasyarakatan (bottom-up), memberikan kesempatan yang lebih luas, insentif dan stimulan yang tepat, informasi terbaru, serta kepercayaan yang lebih besar untuk menjadi bagian integral dari proses berjalannya pemerintahan di daerah. 


\section{Pola Pemberdayaan Masyarakat}

Pemberdayaan adalah rangkaian upaya aktif agar kondisi dan keberadaan adat istiadat, kebiasaan-kebiasaan masyarakat, dan lembaga adat dapat lestari dan makin kukuh, sehingga hal itu berperan positif dalam pembangunan nasional dan berguna bagi masyarakat yang bersangkutan sesuai dengan tingkat kemajuan dan perkembangan zaman.

Pemberdayaan merupakan suatu konsep yang menjelaskan berbagai upaya untuk memperkuat posisi seseorang untuk melalui pertumbuhan kesadaran dan kemampuan individu yang bersangkutan untuk mengidentifikasi persoalan yang dihadapi dan memikirkan langkah-langkah mengatasinya. Inti dari kegiatan pemberdayaan adalah motivasi untuk memahami kondisi dan situasi kerja sehari-hari serta menumbuhkan kemampuan dan keberanian mereka untuk bersikap kritis terhadap kondisi yang mereka hadapi, sehingga kuncinya adalah membangun partisipasi.

Pemberdayaan masyarakat merupakan suatu proses perbaikan yang ditujukan untuk memberikan kemampuan kepada siapapun untuk mampu melakukan sesuatu yangbermanfaat. Salah satu upaya untuk mempercepat proses perbaikan dalam pemeberdayaanmasyarakat adalah pedampingan. Pedampingan sebagai suatu konsep berkembang, dengan adanya kesadaran baru bahwa masyarakat bukanlah pihak yang tidak tahu dan tidak mau maju sebaliknya saat ini mulai dikenali bahwa masyarakat adalah pihak yang mau, memiliki pengetahuan lokal, mempunyai potensi besar serta kearifan tradisional.

Pemberdayaan masyarakat adalah suatu proses dimana masyarakat, khususnya mereka yang kurang memiliki akses kepada sumberdaya pembangunan didorong untuk makin mandiri dalam mengembangkan perikehidupan mereka. Dalam proses ini masyarakat dibantu untuk mengkaji kebutuhan, masalah dan peluang dalam pembangunan yang dimilikinya sesuai dengan lingkungan sosial ekonomi perkehidupan mereka sendiri.

Sasaran utama daripemberdayaan masyarakat adalahmembuka akses bagi kaum yang terpinggirkan dalam pembangunan, termasuk kaum perempuan dan golongan tidak berdaya lainnya. Untuk itu pemberdayaan masyarakat merupakan suatuproses yangberjalan terusmenerus untuk meningkatkankemampuan dan kemandirian masyarakat, menganalisa kondisi dan potensi serta masalah-maslah yang dihadapi.

Pola pemberdayaan masyarakat yang dibutuhkan bukan kegiatan yang sifatnya topdown intervention yang tidak menjunjung tinggi aspirasi dan potensi masyarakat untuk melakukan kegiatan swadaya. Akan tetapi yang paling dibutuhkan masyarakat lapisan bawah terutama yang tinggal didesa adalah pola pemberdayaan yang sifatnya bottom up intervention yang meghargai dan mengakui bahwa masyarakat lapisan bawah memiliki potensi untuk memenuhi kebutuhannya, memecahkan permasalahannya, serta mampu melakukan usahausaha produktif dengan prinsip swadaya dan kebersamaan.

Ross (1987: 77-78) mengemukakan tiga pola pendekatan pemberdyaan dalam rangka peningkatan partisipasi masyarakat di dalam pembangunan, yaitu: 
1. The "singgle Function" adalah program atau teknik pembanguann, keseluruhannya ditanamkan oleh agen pembangunan dari luar masyarakat.

Umumnya pola pendekatan ini kurang mendapat respon dari masyarakat, karena program itu sangat asing bagi mereka sehingga sebagai inovasi yang baik sulit diadopsi. Pola ini menjadikan masyarakat tergantung kepada mereka, sehingga prakarsa masyarakat tidak berkembang.

2. The Multiple Approach, dimana sebuah tim ahli dari luar melaksanakan berbagai pelayanan untuk memcahkan maslah yang dihadapi masyrakat. Pola ini, juga tidak mampu memberdayakan masyarakat secara optimum, karena segala sesuatu tergantung pada tim ahli yang datang dari luar.

3. The Inner Reources Approach, yang menekankan pentingnya merangsang masyarakat untuk mampu mengidentifikasi keinginan-keinginan dan kebutuhan-kebutuhannya dan bekerja secara kooperatif dengan pemerintah dan badan-bdan lain untuk mencapai kepusan bagi mereka. Pola ini mendidik masyarakat menjadi concern akan pemenuhan dan pemecahan masalah yang dihadapi dengan menggunakan potensi yang mereka miliki.

\section{Partisipasi Masyarakat Adat Di Kabupaten Kapuas Hulu, Kalimantan Barat}

Di Kabupaten Kapuas Hulu di dominasi oleh Suku Melayu dan Suku Dayak. Suku Melayu sendiri jika ditelusuri dari silsilah keluarga masih keturunan dari Suku Dayak. Kedua suku tersebut masing-masing mempunyai lembaga adat yaitu MABM (Majelis Adat Budaya Melayu) dan MABD (Majelis Adat Budaya Dayak). Keberadaan lembaga tersebut menjadi sangat signifikan dalam penyelenggaraan pemerintahan di Kabupaten Kapuas Hulu. Tokohtokoh adat dalam lembaga adat merupakan penghubung antara masyarakat adat dan pemerintah. Tokoh-tokoh adat yang biasa disebut Tumenggung dan Panglima perang menjadi panutan bagi masyarakat adat.

Pemerintah Kabupaten Kapuas Hulu mempunyai respon yang sangat besar terhadap masyarakat adat. Salah satu diantaranya dengan memberikan dana insentif per bulan kepada para tokoh adat yang berpengaruh. Pemberian insentif ini khusus diberikan untuk Tokohtokoh Adat Melayu dan Tokoh-tokoh Adat Dayak.

Lembaga adat yang ada di Kabupaten Kapuas Hulu menjadi lokomotif bagi perkembangan demokrasi, sebagai sarana aspiratif dan partisipasi masyarakat. Partisipasi masyarakat adat dalam pelaksanaan pembangunan yang di motori oleh lembaga adat, telah terlihat cukup aktif. Dalam kehidupan sehari-hari Suku Melayu dan Suku Dayak diatur dengan Hukum Adat yang meliputi aturan kesopanan, perkawinan, kejahatan, pertanian, perikanan. Hukum Adat tersebut berguna untuk menjaga keamanan dan ketertiban sesuai dengan norma-norma dan nilai-nilai dan menjadi dasar partisipasi masyarakat adat dalam penyelenggaraan pemerintahan.

Partisipasi yang diberikan masyarakat Kabupaten Kapuas Hulu sesuai dengan Misi Kabupaten Kapuas Hulu, yang salah satunya dinyatakan bahwa perlunya pemberdayaan masyarakat agar dapat tumbuh kesadaran yang tinggi bagi masyarakat untuk memberdayakan 
dirinya sendiri dalam setiap aspek kehidupan bermasyarakat, berbangsa dan bernegara. Kesadaran memberdayakan dirinya sendiri ini diharapkan akan dapat menggerakkan partisipasi aktif masyarakat dalam pelaksanaan pembangunan.

Penguatan terhadap partisipasi yang diberikan masyarakat perlu ditingkatkan, yaitu dengan peningkatan kapasitas yang dilakukan melalui lembaga masyarakat yang senantiasa mengacu pada aspek kearifan lokal dan pengetahuan tradisional yang sudah berkembang di masyarakat adat Kabupaten Kapuas Hulu. Peningkatan kerjasama dengan lembaga lain seperti yang dilakukan pemerintah Kabupaten Kapuas Hulu dengan World Welfare Forestry (WWF), Lanjak Entimau Wildlife Sanctuary, dan Taman Negra Batang Ai (Malaysia) yang sangat membantu partisipasi masyarakat dalam menjaga dan melestarikan lingkungan sekitar.

Masyarakat adat di Kapuas Hulu cukup aktif dalam memberikan aspirasinya, hal ini terlihat dalam berbagai bidang diantaranya:

\section{a. Bidang Hukum dan Kebijakan}

Masyarakat selain ikut serta membantu memerangi dan memberantas kejahatan juga telah membuat Buku Hukum Adat bagi masyarakat adat yang diantaranya berisi tentang sanksi kejahatan. Masyarakat adat Kapuas Hulu terdiri dari banyak suku dan sub suku, bahkan dalam satu sub suku sendiri memiliki tata cara adat yang berbeda satu dengan lainnya, dalam menyelesaikan berbagai perkara di masyarakat.

Tradisi ini tetap dipertahankan sebagai suatu aturan yang masih dipegang teguh oleh masyarakat dan perlu terus dilestarikan dan dipertahankan keberadaannya. Dengan pembentukkan Buku Adat ini selain untuk pelestarian aturan-aturan adat-istiadat itu sendiri juga untuk memperkokoh fungsi lembaga adat, hal ini merupakan usaha yang kondusif terutama dari tokoh-tokoh, pemuka adat atau tumenggung mengetahui dan menyesuaikan diri dengan perkembangan zaman yang senanaiasa berubah.

Awalnya, Hukum Adat merupakan hukum yang tidak tertulis dan cerminan nilai-nilai budaya yang selalu dipegang teguh oleh masyarakat adat, akan tetapi melihat kondisi dan nilai-nilai tersebut mulai mengalami pergeseran seiring dengan masuknya budaya dari luar sehingga dikhawatirkan budaya luar tersebut berpengaruh negatif terhadap budaya masyarakat adat. Oleh karena itu, masyarakat adat bekerjasama dengan Kepolisian dan Pemerintah Kabupaten Kapuas Hulu menerbitkan ’Buku Kumpulan Hukum Adat”.

Dalam hal kebijakan masyarakat adat selalu mendukung dan dilibatkan dalam hal pembuatan kebijakan atau keputusan. Misalnya, program sukses pilkada, program Kabupaten Konservatif, pencegahan narkoba/miras, pencegahan illegal logging serta Penambangan Emas Tanpa Ijin (PETI)/ Illegal Minning. Terhadap Bantuan Kompensasi BBM harga BBM di Kab. Kapuas Hulu diatas harga normal bahkan terkadang harga sampai Rp. 15.000,00, namun demikian tidak ada gejolak seperti daerah lain. Dalam hal pelibatan masyarakat adat, biasanya yang dilakukan oleh Pemerintah Kabupaten Kapuas Hulu yaitu dengan mengundang Tokoh Masyarakat dari setiap masyarakat adat untuk menyalurkan aspirasinya terhadap suatu kebijakan yang sedang di bahas. Kemudian, hasil pembahasan tersebut oleh Tokoh Masyarakat adat di sampaikan kepada masyarakat adat sesuai dengan lokasi Tokoh 
Masyarakat tersebut berada agar mendapat masukan-masukan secara langsung dan dapat menjadi pertimbangan di Dewan Kabupaten Kapuas Hulu.

Dengan diberlakukannya Undang-Undang Nomor 22 tahun 1999 yang telah diubah dengan Undang-Undang Nomor 32 Tahun 2004, membawa manfaat dalam proses demokratisasi di kabupaten Kapuas Hulu. Hal ini terbukti dengan Ketika Pemilihan Presiden dan Pilkada, masyarakat adat ikut menjaga netralitias serta turut aktif mencalonkan dan memilih dengan tenang dan aman, hampir tidak terjadi gejolak.

\section{b. Bidang Pelestarian Sumber Daya Alam}

Berdasarkan Keputusan Bupati Kapuas Hulu Nomor 144 Tahun 2003. Kabupaten Kapuas Hulu selain sebagai daerah otonom juga ditetapkan sebagai Kabupaten Konservasi. Kabupaten Konservasi secara operasional adalah wilayah administratif yang mempunyai komitmen politik untuk menjalankan pelaksanaan pembangunan berlandaskan pemanfaatan berkelanjutan, perlindungan sistem penyangga kehidupan, dan pengawetan keanekaragaman hayati.

Aktivitas pembangunan dalam Kabupaten Konservasi ini bertumpu pada pemanfaatan secara bijaksana sumberdaya alam hayati yang dimiliki dengan prinsip kehati-hatian. Masyarakat dalam hal ini memiliki peranan penting dalam mewujudkan Kabupaten Konservasi. Aktivitas-aktivitas yang dilakukan tidak hanya mengandalkan kearifan tradisional, yaitu memanfaatkan hasil-hasil hutan untuk membiayai keberlangsungan hidup. Kearifan tradisional dimaksudkan sebagai upaya memanfaatkan hutan untuk kepentingan tertentu, misalnya ladang berpindah dan melalui siklus alam.

Masyarakat adat sendiri terhadap keputusan daerahnya di jadikan kabupaten Konservasi awalnya keberatan. Hal ini dikarenakan kebiasaan Masyarakat adat yang tinggal dekat kawasan hutan menjadikan kawasan tersebut sebagai mata pencaharian. Namun usaha agar masyarakat memahami tentang makna dan tujuan berkelanjutan Kabupaten Konservasi ini terus dilakukan dan dimaksimalkan. Pemerintah Kabupaten Kapuas Hulu bekerjasama dengan tokoh Masyarakat adat, Lembaga/organisasi, LSM, dan Organisasi Pemuda di Masyarakat Adat terus aktif melakukan sosialisasi pentingnya Program Pemerintah Kabupaten Konservatif ini. Usaha tersebut saat ini sudah terlihat sedikit nyata dan aktif, yaitu dengan beralihnya mata pencaharian masyarakat adat yang tadinya bersumber dari hasil hutan yang illegal beralih ke pertanian, perkebunan, perikanan, dan pembuatan kerajinan atau barang/alat tradisional yang dapat meningkatkan perekonomian dan melestarikan Budaya di Kapuas Hulu.

\section{c. Bidang Pembangunan Infrastruktur Fisik}

Dimana masyarakat ikut mengontrol langsung pembuatan bangunan fisik seperti jalan dan bangunan/gedung. Sebelum pembangunan prasarana fisik di mulai masyarakat adat sekitar yang berkaitan langsung dengan pembangunan diajak berdialog dan berunding agar dalam pelaksanaannya nanti tidak menimbulkan ketidaksesuaian dengan apa yang diinginkan masyarakat adat. Apabila ternyata tidak sesuai dengan rencana program yang sudah disepakati bersama tadi, maka biasanya masyarakat adat akan melaporkan secara langsung atau mengirimi surat kepada Bupati atau DPRD. 


\section{d. Bidang Pendidikan dan Bidang Pariwisata}

Kabupaten Kapuas Hulu memiliki berbagai potensi bidang kepariwisataan, baik bersifat wisata alam maupun wisata budaya. Wisata budaya berupa kekayaan nilai-nilai tradisional yang masih melekat secara kuat dalam kehidupan sehari-hari. Partisipasi aktif masyarakat adat ditunjukkan melalui tarian-tarian yang dipersembahkan ketika kedatangan Tamu penting, baik itu di masyarakat sendiri ataupun tamu untuk Pemerintah Kabupaten Kapuas Hulu. Hal ini merupakan tradisi yang harus dilakukan dan merupakan sarana untuk melestarikan kebudayaan di Kapuas Hulu. Selain partisipasi aktif diatas, yang dilakukan oleh masyarakat adat yaitu setiap suku aktif mengikuti Festival Budaya yanag diadakan setiap setahun sekali.

\section{e. Bidang Kepemudaan, Olahraga dan Organisasi Perempuan}

Bekerjasama dengan masyarakat adat, Pemerintah Kabupaten Kapuas Hulu mengadakan lokakarya dan seminar. Salah satu Lokakarya yang diadakan yaitu bertema "Adat Istiadat Melayu dan Dayak Se-kabupaten Kapuas Hulu", yang bertujuan untuk menumbuhkembangkan sumber potensi pengembangan Seni Budaya Daerah Kapuas Hulu sebagai Objek dan Daya Tarik Wisata Budaya Daerah, semakin mengaktifkan peran masyarakat adat, budayawan dan pemerhati kebudayaan, dengan lokakarya ini meyakinkan bahwa adat istiadat sebagai norma kehidupan masyarakat sangat bermanfaat bagi kepentingan pendidikan, ilmu pengetahuan, juga persatuan dan kesatuan antar warga.

Peranan Pemuda dan Olah raga di kabupaten Kapuas Hulu dalam pembangunan telah menunjukkan peningkatan diberbagai segi kehidupan masyarakat yang dilakukan oleh organisasi-organisasi kepemudaan baik formal maupun non formal. Adapun kegiatan yang telah dilakukan adalah dibidang kepemimpinan, keolahragaan, perekonomian, maupun sosial kemasyarakatan.

Partisipasi yang diberikan oleh kaum perempuan pun tidak ketinggalan, berbagai program telah menunjukkan hasilnya dalam rangka peningkatan kesejahteraan keluarga, pendidikan, perkoperasian, Keluarga Berencana serta kesehatan Ibu dan Anak. Pada tanggal 26 April 2005 telah dilaksanakan pemilihan pengurus Perempuan Melayu Kabupaten Kapuas Hulu, hal ini mempertegas akan kedudukan dan peranan perempuan dalam pembangunan.

\section{Bentuk-Bentuk Pembinaan Yang Dilakukan Pemerintah Kabupaten Kapuas Hulu}

Selama ini yang dilakukan oleh Pemerintah Kabupaten Kapuas Hulu adalah dengan melakukan pembinaan sesuai dengan instansi yang berkaitan. Memberikan penyuluhan KB, Kesehatan anak dan Ibu, dan Gizi (Dinas Kesehatan), Mengadakan Festival Budaya Dayak, memberikan informasi dengan membagikan buku-buku yang berkaitan dengan budaya masyarakat adat, mengadakan pertemuan rutin setiap tahun sekali atau ketika ada kegiatan yang harus melibatkan masyarakat (Dinas Pariwisata), Memberikan penyuluhan mengenai hukum (misalkan masalah pertanahan), kerjasama membuat buku hukum adat, menerima konsultasi mengenai masalah hukum dengan terbuka kepada masyarakat adat, dan Sosialisasi 
Penegakan Hak Asasi Manusia (Bagian Hukum Pemkab. Kapuas Hulu), Memberikan penyuluhan mengenai bahaya narkoba dan miras, terutama terhadap pemuda/pemudi (Bagian Kesra Pemkab. Kapuas Hulu), Memberikan ceramah-ceramah agama, memfasilitasi untuk diadakan pengajian-pengajian sesama masyarakat adat, pembinaan keorganisasian dan kelembagaan rumah ibadah (Departemen Agama), Melakukan penyuluhan tentang pentingnya pemanfaatan dan pelestarian hutan (Departemen Kehutanan), Melaksanakan program transmigrasi berbasis usaha, khususnya perkebunan rakyat dan pemberian pelayanan administrasi kependudukan secara tepat guna dan tepat sasaran. (Dinas Kependudukan dan Transmigrasi), Sosialisasi Hak Atas Kekayaan Intelektual/ Hak Cipta Pemegang Merek, Pelatihan Kewirausahaan Industri Kecil dan menengah, pemberian bantuan modal kerja kepada kelompok usaha ekonomi produktif non koperasi di desa, dan pelatihan ketrampilan dan desain industri Kecil serta bantuanperalatan (Dinas Perindustrian dan Perekonomian), dan Melakukan pembinaan kelompok tani dengan meningkatkan pengetahuan dan ketrampilan melalui Sekolah lapang, Pelatihan, Kursus, Demonstrasi dan Praktek Percontohan. Pembinaan kemitraan anta kelompok tani dan kelembagaan petani lainnya dengan usaha dibidang pertanian tanaman pangan dan hortikultura (Dinas Pertanian).

\section{Partisipasi Masyarakat Adat Di Kabupaten Katingan, Kalimantan Tengah}

\section{a. Kelembagaan Masyarakat Adat}

Struktur pemerintahan suku dayak sejak zaman purbakala sampai dengan zaman penjajahan Belanda terdiri dari:

1. Tamanggung atau Dambung setingkat dengan Raja (penanggung jawab), melindungi, mensejahterakan, memakmurkan seluruh masyarakat.

2. Pangkalima yang memiliki tangung jawab di bidang pertahanan keamanan.

3. Patih yang memiliki tanggung jawab dalam bidang pemerintahan dan kesejahteraan masyarakat.

4. Damang yang bertanggung jawab pada bidang pengawasan/penuntutan peradilan dan pelestarian lingkungan dibantu oleh para mantir, paralet, para ketua adat. Sedangkan untuk Damang yang cakap dapat diangkat menjadi pimpinan wilayah tertentu.

Perkembangan kelembagaan kedamangan mendapat perhatian serius dari pemerintah Kolonial Belanda, yaitu dengan mengatur dan mengukuhkannya dalam bentuk Besluit Residen Kalimantan Selatan dan Timur, tanggal 28 Oktober 1938, Nomor: 349/C.7-1 tentang penunjukan dari kedamangan-kedamangan (Damang Schapen), yaitu Dayak Hilir (Beneden Dayak), Dayak hulu (Boven Dayak) dan sampit. Kemudian tanggal 15 Februari 1939 ditetapkan Besluit Residen Der Zuider en Oosterafdeeling van Borneo No: 53/C.7-1 tentang Pemilihan, Pemecatan dan Kedudukan para Damang Daerah Kapuas dan Barito. Oleh Masyarakat Dayak Kalimantan Tengah, Besluit berupa penetapan sekaligus sebagai bentuk pengakuan resmi terhadap jabatan-jabatan adat, sekaligus sebagai pengganti jabatan-jabatan adat zaman purba. Sejak tanggal tersebut, secara tertib kerapatan adat dipimpin oleh Damang 
sebagai Kepala Adat, dibantu oleh para penghulu adat dan penasehat dari setiap suku Dayak yang ada di wilayah Kedamangan.

Setelah Kemerdekaan Fungsi lembaga Kedamangan ditetapkan dengan Peraturan Daerah (PERDA). PERDA Nomor : 16/DPR-GR/1969 pertama kali ditetapkan pada tanggal 16 September 1969 tentang Pemilihan Pemilihan, Pengangkatan, Pemecatan Sementara, Pemberhentian dan Penetapan Sementara wilayah Kedamangan serta Tugas dan Kewajiban Damang Kepala Adat Provinsi Kalimantan Tengah, merupakan PERDA pertama kali yang mengatur kelembagaan Adat. Dalam Perda tersebut juga mengatur mengenai hukum adat yang merupakan keseluruhan peraturan-peraturan yang merupakan hukum yang tidak tertulis dan yang mempunyai paksa (sanksi) yang berlaku di daerah Kalimantan Tengah. Perda tersebut menyebutkan bahwa tugas dan tanggung jawab damang adalah berusaha menyelesaikan segala perbantahan dengan jalan damai, memelihara, mengembangkan dan menggali kesenian dan kebudayaan asli serta memelihara benda-benda dan tempat-tempat bersejarah warisan nenek moyang.

Pada perkembangan berikutnya PERDA Nomor: 16/DPR-GR/1969 diganti dengan Perda Nomor 14 Tahun 1998. selanjutnya masing-masing Kota/Kabupaten meninndaklanjuti Perda tersebut dengan menyusun Perda Kedamangan Tingkat Kabupaten/Kota. Kabupaten Katingan sampai saat ini masih mengacu/menggunakan Perda milik Kabupaten Kotawaringin Timur sebagai induk pemekaran yaitu Perda No. 15 tahun 2001 tentang Kedamangan Kabupaten Kotawaringin Timur, akan tetapi Kabupaten Katingan juga berusaha untuk memiliki Perda sendiri yang sampai saat ini masih dalam proses penyusunan.

Dalam Perda Nomor 14 Tahun 1998 dijelaskan bahwa Kedamangan adalah kesatuan masyarakat adat dalam provinsi Daerah tingkat I Kalimantan tengah yang terdiri dari himpunan beberapa desa/kelurahan/kecamatan yang mempunyai wilayah tertentu yang tidak dapat dipisah-pisahkan, wilayahnya tidak terikat dengan wilayah Administrasi Pemerintahan Kecamatan akan tetapi bisa meliputi satu atau beberapa kecamatan. Damang Kepala Adat adalah pimpinan adat, berkedudukan sebagai mitra camat dalam bidang pemberdayaan, pelestarian, pengembangan adat-istiadat, kebiasaan-kebiasaan masyarakat dan lembaga adat serta hukum adat di wilayahnyaDi kabupaten Katingan seorang Damang pada umumnya membawahi 1 wilayah kecamatan, dari 11 kecamatan, baru ada 8 damang, sedangkan Kecamatan yang belum memiliki damang antara Kecamatan Katingan Kuala, Kecamatan Tasik Payaman dan Kecamatan Mendawai.

\section{b. Hukum Adat dan Hak Tradisional Masyarakat Adat Dayak Di Katingan}

Masyarakat Adat Dayak Kalimantan Tengah dan hukum adatnya sebagai bagian dari Masyarakat Adat Nusantara (MAN), telah mengalami kemerosotan peran dan kedaulatan sebagai akibat dari desakan hukum nasional. Lembaga adat Kedamangan dalam realitanya masih ada, namun fungsi dan peranannya pada era kemajemukan dan modernisasi sekarang ini menjadi semakin "kerdil" dan perlu mendapat perhatian serius. Hukum adat Dayak tidak berdasar pada Penjara seperti pada zaman sekarang, dalam memberlakukan hukum adat, seseorang yang salah (kalah) akan menerima "singer" atau denda, dan apabila tidak mampu 
membayar maka harta benda miliknya boleh dirampas atau disita. Apabila tidak memiliki harta benda orang tersebut akan dijadikan "jipen" atau budak, jika ada yang menebus maka seketika itu juga dimerdekakan. Singer yang masih dipegang oleh masyarakat adat Dayak di Kalimantan Tengah juga di Kabupaten Katingan adalah Singer Hukum Adat Dayak Ngaju yang dirumuskan pada rapat besar damai di tumbang Anoi pada tanggal 22 Mei-24 Juli 1894 yang terdiri dari 88 pasal hukum adat dan ditambah 8 pasal aturan dalam kehidupan "Belum Bahadat". Hukum adat tersebut berlaku pada perkara pidana dan Perdata. Dalam perkara pidana, aturan dari hukum adat menghukum segala perbuatan jahat dan pelanggaran adat sopan santun, seperti : 1). Sahiring/pembunuhan, 2). Bali Belum/pembunuhan tidak mati, 3).Biat/luka, 4). Merampas, 5). Membuat rusak harta milik, 6). Sala Hadat/salah adat/ perbuatan tidak sopan, 7). Sala basa/ slah perkataan, 8).Berkelahi, 9). Dan lain-lain., sedangkan pada perkara Perdata seperti: 1). Hukum waris atau pembagian harta, 2). Hak milik/harta benda, 3). Hak perkawinan, 4). Hak perceraian, 5). Hak ketentuan ahli waris), 6).Hak anak bila orang tua bercerai, 7). Hak milik perpantangan, 8). Hak-hak di atas tanah.

Berakhirnya zaman Orde Lama istilah Peradilan Adat berangsur-angsur ditiadakan, seiring dengan keluarnya UU No. 14 Tahun 1970 tentang ketentuan-ketentuan pokok Kehakiman, apalagi yang menyangkut pidana, sehingga istilah yang dipakai berubah menjadi Peradilan/Mejelis Perdamaian Adat sehingga penyelesaian masalah hanya sebatas pada musyawarah. Jika tidak tercapai mufakat pada akhirnya akan diajukan ke tingkat pengadilan.

\section{c. Partisipasi Masyarakat Adat dalam Penyelenggaraan Otonomi}

Peran serta masyarakat adat dalam penyelenggaraan pemerintah sudah ada sejak zaman penjajahan Belanda, Pemberdayaan masyarakat adat yang efektif terjadi sampai dengan berakhirnya zaman Orde Lama. Partisipasi masyarakat adat dilakukan pada bidang penegakan hukum adat, keamanan lingkungan serta kelestarian lingkungan hidup serta dalam melaksanakan sosialisasi kepada masyarakat. Dalam bidang penegakan hukum adat pada umumnya menangani masalah persengketaan tanah, dalam bidang kelestarian lingkungan hidup menangani masalah illegal mining dan illegal logging, dalam bidang keamanan menangani perselisihan inter dan antar suku dan bidang kebudayaan dalam rangka melestarikan kebudayaan Dayak.

Pada era otonomi daerah partisipasi masyarakat adat di Kabupaten Katingan tidak begitu optimal meskipun kelembagaan masyarakat adat kedamangan masih tetap eksis, hal ini disebabkan minimnya pemberdayaan pemerintah terhadap masyarakat adat ataupun kelembagaan adat tersebut.

Damang dalam melaksanakan tugasnya mendapatkan penghasilan dari pemerintah daerah yang dialokasikan pada anggaran Kecamatan akan tetapi penghasilan yang diterima selama ini sangatlah minim, jauh di bawah Upah Minimum Regional (UMR) daerah, dengan upah yang kecil tentunya tidak sebanding dengan tugas seorang damang seperti yang diatur dalam Perda Nomor 14 Tahun 1998, sehingga Damang sendiri mengibaratkan dirinya sendiri seperti ungkapan "Hidup Segan Mati tak Mau". Hal ini sangatlah lumrah apalagi jika dikaitkan dengan peran mereka yang sangat diharapkan oleh daerah akan tetapi kesejahteraan 
tidak diperhatikan. Selama ini usaha pemerintah dalam meningkatkan partisipasi masyarakat adat terutama kepada kepala adat hanyalah monumental saja, seperti adanya Pilkada, saat terjadinya kerusuhan yang tidak mampu di atasi oleh pemerintah, ataupun sosialisasi terhadap masyarakat yang biasanya akan lebih efektif jika dilakukan oleh Damang.

\section{d. Pembinaan terhadap masyarakat Adat di Katingan}

Pembinaan yang dilakukan oleh pemerintah Kabupaten Katingan ditangani oleh beberapa dinas disesuaikan dengan bidang-bidang yang ditangani, dalam bidang kelembagaan masyarakat adat pembinaan ditangani oleh bagian pemerintahan setda Kabupaten Katingan, Bidang Kebudayaan (promosi daerah) ditangani oleh dinas pariwisata, Bidang pendidikan budaya ditangani oleh dinas pendidikan dan kebudayaan, bidang prestasi yang ditangani oleh BAPORA serta bidang pemberdayaan ditangani oleh dinas sosial dan pemberdayaan masyarakat. Pembinaan yang dilakukan oleh bagian pemerintahan berupa sosialisasi pertemuan Majelis adat, fasilitasi pemilihan damang serta masalah lainnya yang berhubungan dengan kelembagaan. Dalam bidang kebudayaan Kabupaten Katingan beberapa kali mewakili Provinsi Kalimantan Tengah dalam mempromosikan kebudayaan khususnya budaya Dayak. Upaya pemerintah untuk melakukan pembinaan sudah cukup baik baik dengan adanya penanganan pembinaan oleh beberapa dinas, akan tetapi pembinaan yang dilakukan belum optimal, tidak secara kontinuitas hanya pada momen-momen tertentu saja sehingga hasilnya pun tidak maksimal.

\section{e. Hukum Adat dan Hak Tradisional Masyarakat Adat Dayak}

Masyarakat Adat Dayak Kalimantan Tengah dan hukum adatnya sebagai bagian dari Masyarakat Adat Nusantara (MAN), telah mengalami kemerosotan peran dan kedaulatan sebagai akibat dari desakan hukum nasional. Lembaga adat Kedamangan dalam realitanya masih ada, namun fungsi dan peranannya pada era kemajemukan dan modernisasi sekarang ini menjadi semakin "kerdil" dan perlu mendapat perhatian serius. Hukum adat Dayak tidak berdasar pada Penjara seperti pada zaman sekarang, dalam memberlakukan hukum adat, seseorang yang salah (kalah) akan menerima "singer" atau denda, dan apabila tidak mampu membayar maka harta benda miliknya boleh dirampas atau disita. Apabila tidak memiliki harta benda orang tersebut akan dijadikan "jipen" atau budak, jika ada yang menebus maka seketika itu juga dimerdekakan. Singer yang masih dipegang oleh masyarakat adat Dayak di Kalimantan Tengah juga di Kabupaten Katingan adalah Singer Hukum Adat Dayak Ngaju yang dirumuskan pada rapat besar damai di tumbang Anoi pada tanggal 22 Mei-24 Juli 1894 yang terdiri dari 88 pasal hukum adat dan ditambah 8 pasal aturan dalam kehidupan "Belum Bahadat". Hukum adat tersebut berlaku pada perkara pidana dan Perdata. Dalam perkara pidana, aturan dari hukum adat menghukum segala perbuatan jahat dan pelanggaran adat sopan santun, seperti : 1). Sahiring/pembunuhan, 2). Bali Belum/pembunuhan tidak mati, 3).Biat/luka, 4). Merampas, 5). Membuat rusak harta milik, 6). Sala Hadat/salah adat/ perbuatan tidak sopan, 7). Sala basa/ slah perkataan, 8).Dosa/berzina dengan perempuan bersuami atau perawan, 9).Tungkun/merampas atau mengambil istri orang lain, 10). Dosa/memaksa perempuan berzinah, 11). Membuat rebut atau kalut dalam persidangan, 12). Menghina kepala-kepala atau Mantir dalam persidangan, 13). Membuat malu, 14). Fitnah, 
15).Berkelahi, 16).Memaki, 17). Masuk rumah orang tanpa izin, 18). Dan lain-lain., sedangkan pada perkara Perdata seperti: 1). Hukum waris atau pembagian harta, 2). Hak milik/harta benda, 3). Hak perkawinan, 4). Hak perceraian, 5). Hal ketentuan ahli waris), 6).Hal anak bila orang tua bercerai, 7). Hal milik perpantangan, 8). Hal-hal di atas tanah.

Berakhirnya zaman Orde Lama istilah Peradilan Adat berangsur-angsur ditiadakan, seiring dengan keluarnya UU No. 14 Tahun 1970 tentang ketentuan-ketentuan pokok Kehakiman, apalagi yang menyangkut pidana, sehingga istilah yang dipakai berubah menjadi Peradilan/Mejelis Perdamaian Adat sehingga penyelesaian masalah hanya sebatas pada musyawarah. Jika tidak tercapai mufakat pada akhirnya akan diajukan ke tingkat pengadilan.

\section{e. Upaya Peningkatan Partisipasi Masyarakat Adat Katingan}

Upaya pemerintah Kabupaten Katingan dalam meningkatkan pemberdayaan/partisipasi masyarakat adat, terutama untuk mengoptimalkan peran damang belumlah maksimal. Pertemuan Majelis adat yang diselenggarakan oleh Dinas Pendidikan Nasional Provinsi Kalimantan Tengah pada tanggal 17 November 2005 yang dihadiri oleh 60 Damang (diantaranya adalah Damang dari Kabupaten Katingan) se-Kalimantan Tengah menghasilkan beberapa rumusan yang cukup memberikan angin segar bagi kelembagaan masyarakat adat khususnya Dayak serta kesejahteraan Kepala Adat. Dalam pertemuan tersebut dihasilkan beberapa rumusan antara lain:

1. Penambahan Honor senilai Rp. 300 ribu, jumlah ini masih di bawah Upah Minimum Regional, akan tetapi sudah meningkat hampir mencapai $50 \%$ dibanding sebelumnya yang rata-rata sebesar Rp. 175.000;

2. Pertemuan Damang se-Kalteng minimal tiga tahun sekali ,;

3. Tahun 2006 seluruh Damang studi banding ke Bali;

4. Struktur kelembagaan Damang perlu segera dibentuk;

5. Jabatan Damang dibatasi, baik batas usia minimum maupun maksimum;

6. Perlu dirumuskan hukum adat setempat;

7. Perlu diadakan pekaian adat masing-masing daerah.

Disamping itu untuk melestarikan adat-istiadat Damang juga difungsikan sebagai penutur budaya di sekolah-sekolah, juga diusulkan muatan lokal yang mempelajari adatistiadat terutama budaya Dayak agar tidak luntur terutama di kalangan pemuda. Keputusankeputusan ini tentunya menjadi pemicu semangat para Damang untuk terus melestarikan adat-istiadat maupun pemberlakuan kembali hukum adat yang lebih efektif diterapkan pada masyarakat adat.

Dalam paparannya Kepala Polisi Daerah (Kapolda) Kalimantan $T$ engah juga mengungkapkan bahwa konsep upaya pencegahan terhadap gangguan keamanan dan ketertiban masyarakat dengan mengikutsertakan masyarakat itu sendiri melalui peranan Damang pada kehidupan masyarakat adat di dalam menciptakan keamanan dan ketertiban dengan pola pengatur alam pikiran masyarakat setempat masih dipandang sangat efektif untuk meyelesaikan masalah-masalah sosial yang ada di masyarakat lokal. Bahkan Kapolda mengemukakan wacana konsep penerapan Konsep POLMAS (Polisi Masyarakat) dengan memanfaatkan keberadaan Damang di masyarakat sebagai mitra untuk mendukung tugas 
Polri di dalam pemeliharaan keamanan dan ketertiban masyarakat, penegakan hukum serta dalam tugas melindungi, mengayomi dan melayani masyarakat.

Jika pemerintah daerah Provinsi Kalimantan Tengah benar-benar ingin menghidupkan kembali peran masyarakat dalam pembangunan daerah dalam penyelenggaraan otonomi daerah khususnya terhadap Damang kepala Adat, tentunya hasil pertemuan para damang tersebut bukan hanya sekedar menghasilkan beberapa rumusan, keinginan atau pun wacana saja akan tetapi benar-benar diwujudkan dalam tindakan nyata. Karena upaya pemerintah Kabupaten/kotamadya untuk meningkatkan partisipasi/ pemberdayaan masyarakat adat terutama menghidupkan kembali lembaga-lembaga adat sangat ditentukan oleh kebijakan dari Pemerintah Provinsi.

\section{Partisipasi Masyarakat Adat Dalam Penyelenggaraan Otonomi Daerah Di Kabupaten Tanah Laut, Kalimantan Selatan}

Jumlah penduduk Kabupaten Tanah Laut (TALA) pada tahun 2004 berdasarkan hasil registrasi sebesar 243.762 orang. Hingga sekarang TALA masih menjadi wilayah transmigrasi yang menarik. Setiap tahun, selalu ada pendatang baru ke kabupaten yang disebut Bumi Tuntung Pandang (bumi abadi selamanya) ini. Transmigran terbanyak dari Jawa. Menurut Sensus Penduduk 2000, yang tinggal di kabupaten ini 243.762 jiwa, terdiri 61,7 persen orang Banjar, 31,5 persen Jawa, dan sisanya Bugis, Madura, Sunda, serta lainnya. Tahun 2002, 238 keluarga (885 jiwa) dari Provinsi DI Yogyakarta, Jawa Timur, Nusa Tenggara Timur, Nusa Tenggara Barat, dan daerah lain datang ke TALA mengadu nasib.

Berdasarkan komposisi penduduk TALA tersebut, jelas tergambarkan bahwa komposisi penduduk TALA sangat heterogen dan merupakan pendatang. Jika ditelusuri sejarah berdirinya TALA sebagai Daerah Tingkat II ditandai secara "resmi" ditandai dengan peresmian Kantor Persiapan Daerah Tingkat II pada tahun 1964, maka keberadaan TALA dapat dikategorikan sebagai daerah yang relatif baru.

Fakta-fakta tersebut yang melatarbelakangi sulitnya mengidentifikasi eksistensi dan tingkat partisipasi masyarakat adat. Keberadaan masyarakat tradisional, baik dilihat dari tatanan sosial maupun ekonomi di TALA tidak ada yang signifikan.

\section{Kesimpulan Dan Rekomendasi}

Masyarakat yang berdaya, adalah masyarakat yang dinamis dan aktif berpartisipasi didalam membangun diri mereka. Tidak menggantungkan hidupnya kepada belas kasihan orang lain. Mereka mampu berkompetensi dalam kontek kerjasama dengan pihak lain. Mereka memiliki pola pikir kosmopolitan, memiliki wawasan berpikir yang luas,cepat mengadopsi inovasi, toleransi tinggi, dan menghindari konflik sosial. Sosok masyarakat 
seperti itulah yang menjadi sasaran dari program pemberdayaan dan peningkatan partisipasi masyarakat.

Dengan kata Lain, tujuan dilaksanakannya program pemberdayaan tidak terhenti pada keterlibatan kelompok masyarakat secara aktif dalam proses pengambilan kebijakan didaerah, namun berlanjut terus hingga terwujudnya konsepsi masyarakat madani (civil society), yakni masyarakat yang memiliki daya tawar (bargaining power) dan kemandirian (indepedency) baik secara poltis, ekonomis, maupun sosial kemasyarakatan.

Dari hasil penelitian ini dapat disimpulkan bahwa secara umum tingkat partisipasi masyarakat cukup menggembirakan di daerah-daerah yang disurvei. Pola partisipasi yang dipraktekkan juga cukup beragam, dari pemberian donasi, keikutsertaan dalam kegiatan tertentu, monitoring dan pengawasan serta pengamaan aset negara (seperti illegal logging, penambangan liar, dll), penanganan perselisihan inter dan antar suku, pemeliharaan prasarana fisik dan fasilitas umum (misalnya jalan, jembatan dan bangunan/gedung), dukungan terhadap kebijakan tertentu dari pemerintah daerah (misalnya dalam hal penetapan status sebagai daerah konservasi, atau dalam pelaksanaan pilkada langsung), mengembangkan budaya dan kesenian tradisional dalam rangka mempromosikan industri pariwisata daerah dan sebagainya.

Namun sayangnya, selama ini terkesan bahwa upaya pemerintah untuk mendorong tumbuhnya partisipasi publik belum tersusun secara sistematis dan terstruktur. Akibatnya, partsisipasi lebih berjalan atas inisiatif mandiri dari masyarakat, namun kurang didukung oleh kebijakan publik sebagai leveraging factor-nya. Selain itu, kendala-kendala klasik seperti keterbatasan anggaran, keterbatasan SDM, dan luasnya jangkauan wilayah, selalu menjadi alasan pembenar terhadap lemahnya partisipasi publik.

Berdasarkan penjelasan diatas, semoga rekomendasi ini dapat memberikan manfaat bagi peningkatan partisipasi masyarakat adat dalam penyelenggaraan otonomi daerah.

1. Melaksanakan pemberdayaan masyarakat adat hendaknya secara bertahap, disesuaikan dengan tingkat pemahaman dan respon dari masyarakat yang dibina, serta bersifat natural dan tidak terkesan dipaksakan. Dengan tetap berusaha meningkatkan kualitas pemberdayaan itu sendiri dan menerima segala masukan dari berbagai pihak demi tercapainya cita-cita pembangunan nasional.

2. Pertemuan antar Pemerintah Kabupaten dengan masyarakat adat secara rutin dan terjadwal;

3. Pemberian dana insentif yang lebih besar kepada masyarakat adat.

4. Memberikan Akses dan arus informasi yang terbuka merupakan rujukan pegetahuan bagi warga untuk berpartisipasi. Yang paling dasar informasi memberi pasokan pengetahuan untuk berpartisipasi.

5. Memperbanyak tenaga penyuluh yang berkualitas dan memiliki kesadaran untuk memajukan masyarakat adat. Terutama di bidang-bidang yang sesuai dengan mata pencaharian masyarakat tersebut, seperti pertanian, perternakan, dan kerajinan tangan.

6. Mengusahakan pemasaran yang baik untuk meningkatkan taraf hidup mereka, seperti kerajinan rotan, damar, dan kayu. 
7. Meningkatkan mutu pendidikan, seperti; menerjunkan para tenaga pendidik yang berkualitas dengan memberikan rangsangan tunjangan yang lebih besar lagi. Hal ini diperuntukkan karena medan yang dihadapi jauh lebih sulit dibandingkan dengan pengajaran di kota.

\section{Referensi}

\section{BUKU, MAKALAH DAN LAPORAN}

Abang Tambul Husin, Kabupaten Konservasi, Gramedia, Jakarta, 2005

Ardjunan Walan, Drs., 2005, Peranan Damang dalam Upaya Menegakkan Keamanan dan Ketertiban di Daerah Kalteng. Bahan diskusi dalam Rapat Damang Kepala Adat dengan Gubernur Provinsi Kalimantan Tengah Tanggal 17 November 2005 di Palangka Raya

Ashari Gusti Z., dkk, Aturan-Aturan Tradisonal Basis Pengelolaan Taman Nasional Danau Sentarum, Yayasan Konservasi Borneo (bekerja sama dengan NC - IUCN (The World Convervation Union)

Bunga Rampai Majelis Adat Budaya Melayu (MABM) Kabupaten Kapuas Hulu.

Gunawan Jamil, et al, Desentralisasi Globlalisasi dan Demokrasi Lokal, Pustaka LP3ES Indonesia, Jakarta, 2005

Institute for Research and Enpowerment (IRE), Prakarsa Desentralisasi dan Otonomi Desa, Yogyakarta, 2005

Kumpulan Hukum Adat di Kabupaten Kapuas Hulu, Bagian Hukum Sekretariat Daerah Kabupaten Kapuas Hulu

s, BPS, 2004,

Laporan Kegiatam Pengurus MABM Kabupaten Kapuas Hulu Tahun 2005, Dewan Pengurus MABM

Siun, Drs., SH., M.H, Dr., 2005. Eksistensi Hukum Adat, Lembaga Adat dan Hak Tradisional Masyarakat Dayak di Kalimantan Tengah. Bahan diskusi dalam Rapat Damang Kepala Adat dengan Gubernur Provinsi Kalimantan Tengah Tanggal 17 November 2005 di Palangka Raya

Membangun Citra Positif Hukum Adat dan Adat istiadat Dayak dan Melayu, Abdullah usman, Lokakarya Istiadat Dayak dan Melayu Se-Kabupaten Kapuas Hulu, 08 Februari 2005, Hotel Merpati Putussibau. 
Panduan Pelaksanaan Community Empowerent dalam Agenda Konservasi WWF-Indonesia, Tim Inti Kelompok Kerja Community Emporwement WWF - Indonesia, Desember 2004

Pengakuan Hak Ulayat Oleh Pemerintah Hanyalah Wacana Mimpi Buruk pada masyarakat Suku Bangsa Dayak (Suatu Tinjauan dari Politik Hukum), Jacobus F. Layang BA, $\mathrm{SH}$

Profil Objek Wisata Kabupaten Kapuas Hulu, Dinas Pariwisata dan Kebudayaan Daerah Kabupaten Kapuas Hulu

Program Pembangunan Daerah (Propeda) Kabupaten kapuas Hulu Tahun 2001-2005, Pemerintah kabupaten Kapuas Hulu, 2003.

Rencana Stratejik (renstra) Pengelolaan Kawasan Hutan Wilayah Perbatasan RI- Malaysia Di Kalimantan

Wawancara dengan Bapak Nyahun (Damang wilayah kecamatan Tewang Sangalang Garing) $\underline{\text { www.tempointeraktif.com }}$

\section{KORAN DAN MAJALAH}

Dayak Pos. Tanggal 19 November 2005.

Kalteng Pos. Tanggal 17 November 2005.

Kalteng Pos. Tanggal 18 November 2005.

Kalteng Pos. Tanggal 19 November Tahun 2005.

Kompas, Selasa, 20 Desember 2005. (Jangan Lupakan Masyarakat Adat)

Tempo, Kamis, 17 Juni 2004. (Hak-Hak Masyarakat Adat danMasalah serta Kelestarian Lingkungan Hidup di Indonesia)

Warta Kebijkan CIFOR No. 2 Februari 2002 (Masyarakat Adat)

\section{PERATURAN PERUNDANG-UNDANGAN}

Undang-Undang Nomor 32 Tahun 2004 tentang Pemerintahan Daerah

Perda Provinsi Kalimantan Tengah Nomor 14 Tahun 1998

SK Keputusan Kepala Dinas Pariwisata dan Kebudayaan Daerah Kabupaten Kapuas Hulu No. 5 tahun 2004 Tentang Pembentukkan Tim Teknis Penyelenggaraan Lokakarya Adat Istiadat Melayu dan Dayak Se-Kabupaten Kapuas Hulu 


\title{
REVITALISASI KEBIJAKAN \\ PEMBANGUNAN KEHUTANAN DI KALIMANTAN TIMUR PERIODE LIMA TAHUN KE-2 OTONOMI DAERAH (2006-2010)
}

\author{
Oleh: H. Rusdi Manaf ${ }^{6}$ dan Daroni ${ }^{7}$
}

\begin{abstract}
East Kalimantan's natural resources have been the main sector in terms of financial contribution to the national income. Reforestration fund, provision of forest resources, export taxes, and other significant levies, have taken essential part in bearing the national development processes. This implies the positive roles of Kalimantan forest, for which it should be properly managed. Until recently, unfortunately, forest management has been observed to be unsuccsesful as indicated by depletion and degradation of forest areas during the first period of the implementation of regional autonomy (2001-2005). Under the new vision "forest management for the shake of resource sustainability and people's wellbeing”, the following efforts are truthfully required: reassessment of performance measurement, revitalization through soft landing, reinforcing forest rehabilitation movement, reevaluation of policies concerning administrative approval (perijinan), etc. The ultimate goal of such endeavors is to achieve the optimum equilibrium of the forest function, i.e. between economic interest and ecological interest.
\end{abstract}

Keywords: kinerja kehutanan, kapasitas kelembagaan, restrukturisasi dan revitalisasi, peranan ekologis dan sosial ekonomi hutan.

\section{Latar Belakang}

Propinsi Kalimantan Timur mempunyai luas daratan sekitar $200.395 \mathrm{~km}^{2}$, merupakan Propinsi terbesar di Indonesia. Luas daratan Kalimantan Timur kira-kira sama dengan satu setengah kali Pulau Jawa dan Madura. Dari luas tersebut, 15,952 juta hektar atau sekitar 75 persennya adalah berupa kawasan hutan (hutan suaka alam dan wisata, hutan lindung, hutan produksi terbatas, hutan produksi tetap dan hutan penelitian) dan 4,088 juta hektar merupakan hutan produksi yang dapat dikonversi.

Kawasan hutan tersebut meliputi kawasan hutan suaka alam dan hutan lindung seluas 2,752 juta hektar (17,252\%), hutan penelitian 23,5 ribu hektar $(0,15 \%)$ dan Kawasan budidaya kehutanan (hutan produksi tetap dan hutan produksi terbatas) Kalimantan Timur

\footnotetext{
6 Ir. H. Rusdi Manaf, M.Si adalah Plt. Kepala Dinas Kehutanan Propinsi Kalimantan Timur.

7 Dr. Daroni, SIP.,SP.,MP adalah Staf Dinas Kehutanan Provinsi Kalimantan Timur dan Staf Pengajar STIEM Samarinda
} 